\title{
Pengaruh Pembayangan terhadap Kenyamanan Termal pada Rumah Tinggal di Perumahan Bukit Baruga Antang Makassar
}

\author{
Jumriya, Rosady Mulyadi, Baharuddin Hamzah \\ Departemen Teknik Arsitektur, Fakultas Teknik, Universitas Hasanuddin \\ Jl. Poros Malino km. 6, Bontomarannu, Kabupaten Gowa, Sulawesi Selatan 92171 \\ *Email: jumriya04@gmail.com, rosadyd51rm@gmail.com, baharsyah@yahoo.com
}

DOI: 10.25042/jpe.052019.xx

\begin{abstract}
Abstrak
Penelitian ini dilakukan dengan mengukur kenyamanan termal alami dan mengetahui seberapa besar pengaruh tanaman peneduh terhadap kenyamanan termal alami didalam rumah tinggal. Rumah tinggal dikelompokkan menjadi dua kelompok yaitu rumah tinggal yang ada tanaman peneduh dan rumah tinggal yang tidak ada tanaman peneduh. Data pengukuran statis dilakukan dengan beberapa variabel kenyamanan berupa suhu, kelembaban, dan kecepatan angin kemudian diukur menggunakan alat HOBO temp/RH logger dengan waktu pengukuran dari pukul 06.00-18.00 WITA. Hasil penelitian menunjukkan bahwa rata-rata temperatur tertinggi untuk rumah tinggal yang ada tanaman peneduh $30,2{ }^{\circ} \mathrm{C}$ dan rumah tinggal yang tidak ada tanaman peneduh $31,3{ }^{\circ} \mathrm{C}$. Kemudian rata-rata kelembaban tertinggi rumah tinggal yang ada tanaman peneduh $73 \%$ dan yang tidak ada tanaman peneduh $73 \%$, dengan ini kelembaban berada pada zona yang nyaman. Sedangkan hasil rata-rata $0,19 \mathrm{~m} / \mathrm{s}$ untuk kecepatan angin tertinggi rumah tinggal yang tidak ada tanaman peneduh dan 0,65 $\mathrm{m} / \mathrm{s}$ rumah tinggal yang ada tanaman peneduh. Hasil survey kenyamanan penghuni menunjukkan sebagian responden masih merasa nyaman namun tetap mengharapkan kondisi kenyamanan termal yang lebih sejuk lagi. Responden beradaptasi dengan kondisi lingkungannya dengan cara memilih pakaian yang nyaman dan tipis serta mengurangi kegiatan yang menimbulkan banyak keringat.
\end{abstract}

\begin{abstract}
The Effect of Shade on Thermal Comfort in Residential Houses in Bukit Baruga Antang Makassar. This research was conducted by measuring natural thermal comfort and knowing how much influence the shade plants have on natural thermal comfort in the house. Dwellings are grouped into two groups namely dwellings with shade plants and dwellings with no shade plants. Static measurement data is carried out with several comfort variables in the form of temperature, humidity, and wind speed and then measured using a HOBO temp / RH logger tool with measurement time from 06.00-18.00 WITA. The results showed that the average highest temperature for houses with shade plants was $30.2^{\circ} \mathrm{C}$ and houses without shade plants were $31.3{ }^{\circ} \mathrm{C}$. Then the highest average humidity of residential houses with $73 \%$ shade plants and $73 \%$ without shade plants, with this humidity is in the comfort zone. While the average yield of $0.19 \mathrm{~m} / \mathrm{s}$ for the highest wind speed of houses without shade plants and $0.65 \mathrm{~m} / \mathrm{s}$ of shade houses. The results of the occupants comfort survey show that some respondents still feel comfortable but still expect cooler conditions of thermal comfort. Respondents adapt to environmental conditions by choosing comfortable and thin clothing and reducing activities that cause a lot of sweat.
\end{abstract}

Kata Kunci: Kenyamanan termal, rumah tinggal, responden penghuni, tanaman peneduh

\section{Pendahuluan}

Makassar adalah salah satu kawasan strategis yang mengalami pertumbuhan yang sangat pesat diberbagai sektor dan menjadi penyebab tingginya pertumbuhan pembangunan perumahan. Bagi manusia rumah tinggal adalah tempat dimana mereka dapat beraktifitas sebebas mungkin oleh karena itu mereka membutuhkan kenyamanan untuk mengendalikan kondisi pribadi. Kenyamanan termal yaitu respon yang dirasakan oleh sensor perasa kulit terhadap suhu di lingkungan sekitarnya berupa sensasi panas atau dingin. Menurut Olgyay [1], kondisi iklim di sekitar dapat meningkatkan produktivitas dan kesehataan manusia. Tingkat produktivitas dapat mencapai titik maksimum jika kondisi iklim (seperti suhu udara, kelembaban, angin, hujan, dsbnya) memenuhi kebutuhan fisik manusia.

Ketidaknyamanan termal dapat diakibatkan karena suhu udara yang terlalu panas dan dipengaruhi oleh radiasi sinar matahari yang 
tinggi. Pembayangan adalah salah satu faktor yang perlu dipertimbangkan untuk meminimalkan ketidaknyamanan termal akibat radiasi matahari langsung di ruang terbuka [2]. Seperti yang dikatakan oleh Wong dkk [3], dengan adanya vegetasi dapat menjadi peranan penting bagi iklim perkotaan dan iklim mikro didalam bangunan. Vegetasi selain memberikan konstribusi dalam menciptakan kenyamanan ruang didalam bangunan juga dapat memberi penghematan energi. Tanaman peneduh yang sudah dewasa biasanya memiliki percabangan yang tingginya lebih 3-4 meter dengan lebar tajuk yang dapat memberi keteduhan bagi penggunanya.

Berdasarkan penelitian Santoso dan Eddy Imam [4], suhu udara dalam ruangan dapat turun dengan ditempatkan penahan sinar matahari dari vegetasi yang ditempatkan secara vertical maupun horisontal. Tanaman peneduh dapat dipertimbangkan dalam pencapaian kenyamanan termal yang dapat dimanfaatkan dalam proses adaptasi manusia terhadap lingkungannya.

Standar kenyamanan termal yang dapat digunakan di Indonesia yaitu SNI T-14-1993-03, untuk temperature: Sejuk nyaman $20,5{ }^{\circ} \mathrm{C}-$ 22,8 ${ }^{\circ} \mathrm{C}$, Nyaman optimal $22,8{ }^{\circ} \mathrm{C}-25,8{ }^{\circ} \mathrm{C}$, Hampir nyaman $25,8{ }^{\circ} \mathrm{C}-27,1{ }^{\circ} \mathrm{C}$. Untuk kelembaban, sejuk nyaman kelembaban relatif $50 \%-80 \%$, Nyaman optimal kelembaban relatif $70 \%-80 \%$, hampir nyaman kelembaban relatif
$60 \%$ - 70\%. Tingkat aliran udara yang baik sebesar $0,25-1,5 \mathrm{~m} / \mathrm{s}$ [5].

Penelitian ini bertujuan untuk mengkaji kenyamanan termal alami dan perilaku adaptif rumah tinggal pada kondisi yang nyata dengan mengetahui kenetralan kondisi termal, keterterimaan kondisi termal, dan preferensi kondisi termal penghuni dan penghuni saat merespon kondisi lingkungannya. Berdasarkan uraian diatas maka dianalisis perbedaan antara kondisi termal pada rumah-rumah tinggal yang tidak ada tanaman peneduh dan rumah-rumah tinggal yang ada tanaman peneduh dengan dilakukan pengukuran temperatur, kelembaban dan kecepatan angin.

\section{Metode}

Penelitian ini menggunakan metode kuantitatif dan kualitatif. Metode kuantitatif merupakan metode penelitian yang lebih menekankan pada pengukuran secara objektif dan yang kualitatif adalah hasil akhir yang berupa angka dari persepsi penghuni yang diambil dan dimasukkan kedalam kategori kata-kata. Lokasi penelitian terletak di kawasan perumahan Bukit Baruga Antang, Kecamatan Manggala, Kota Makassar, Provinsi Sulawesi Selatan (Gambar 1).
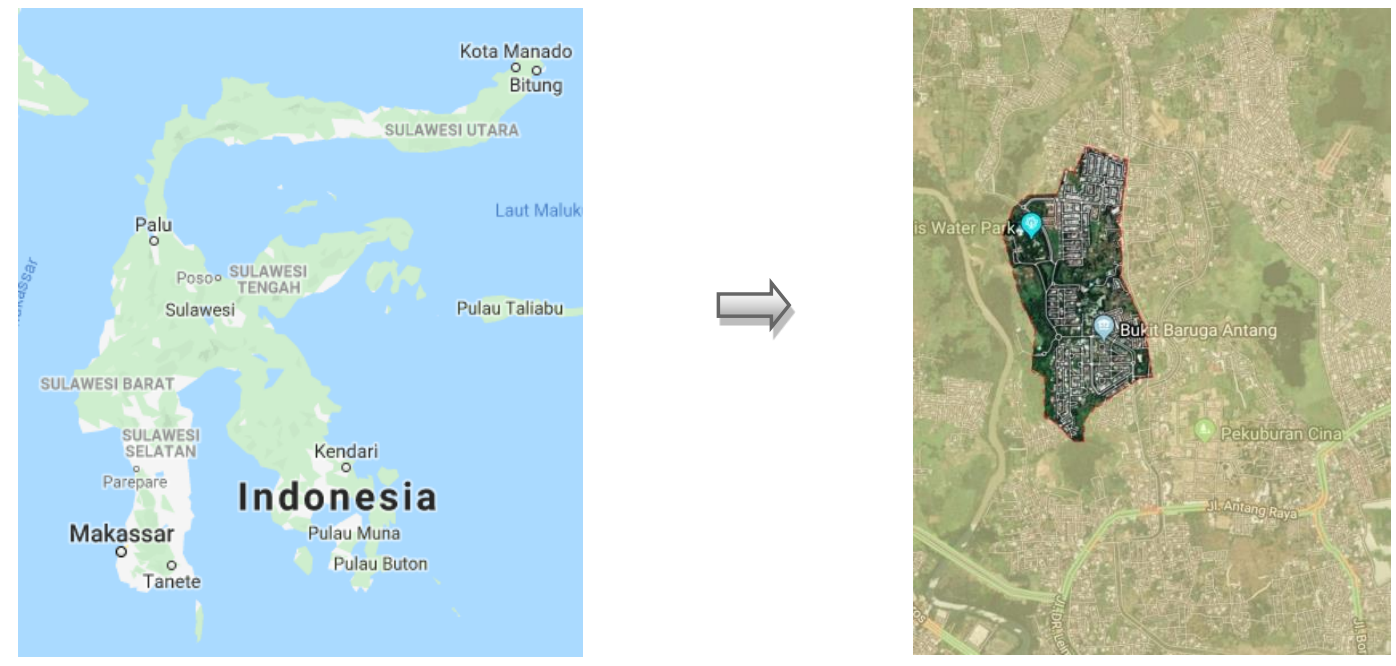

Gambar 1. Peta bukit baruga antang 
Penelitian dilakukan pada rumah-rumah tinggal yang dikelompokkan menjadi dua kategori yaitu rumah tinggal yang ada tanaman peneduh dan rumah tinggal yang tidak ada tanaman peneduh, dengan karekteristik luas lantai bangunan $\leq 54 \mathrm{~m}^{2}$, tinggi plafon $\leq 3,5 \mathrm{~m}$. Tanaman peneduh dengan kriteria memiliki ketinggian batang sekitar $\pm 4 \mathrm{~m}$ dari permukaan tanah, dengan kanopi berdiameter sekitar $\pm 6 \mathrm{~m}$ dan jarak \pm 3 meter dari dinding terluar bangunan. Untuk rumah tinggal yang ada tanaman peneduhnya, tanaman peneduhnya berada di bagian depan rumah tinggal (Gambar 2).

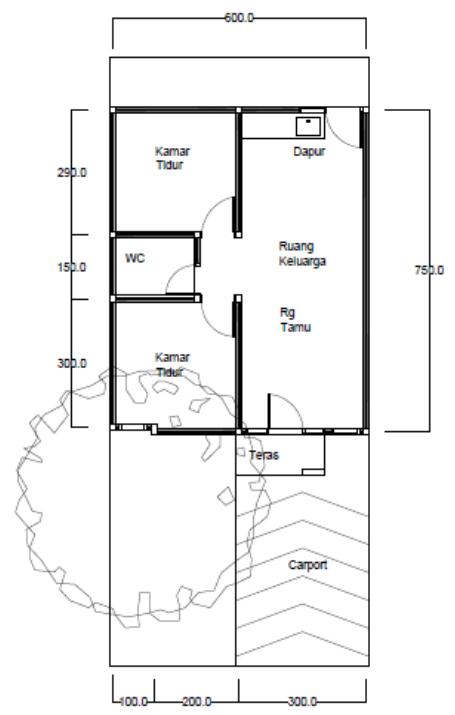

Gambar 2. Lokasi tanaman peneduh

Kemudian data yang diukur yaitu kenyamanan termal yaitu temperatur, kelembaban, dan kecepatan angin di dalam rumah tinggal. Ruangan yang dilakukan pengukuran pada rumah tinggal yaitu ruang tamu, ruang keluarga, dan ruang tidur. Orientasi rumah diambil dengan kondisi orientasi yang berbeda-beda pada satu lingkungan perumahan. Adapun data penghuni yang diambil menggunakan kuesioner yang diisi bersamaan saat pengukuran dilakukan yaitu mengenai tingkat kenyamanan yang dirasakan penghuni.

Hasil penelitian terbagi menjadi dua yaitu data kuantitatif yang dilakukan dengan melakukan pengukuran secara langsung dengan menggunakan alat ukur HOBO temp/RH logger terhadap 3 variabel kenyamanan termal alami yaitu temperatur, kelembaban, kecepatan angin dan data kualitatif adalah hasil penelitian dari data kuesioner yang dibagikan kepada pengguna bangunan rumah tinggal sehingga dapat diketahui sensasi termal yang dirasakan di dalam rumah tinggal oleh penghuni.

\section{Hasil dan Pembahasan}

Hasil pengukuran temperature dapat dilihat pada Gambar 3, dimana temperatur udara dalam rumah-rumah tinggal yang tidak ada tanaman peneduh pada tanggal 15-30 November 2018 dari pukul 06.00:18.00 WITA menunjukkan rata-rata $30,39{ }^{\circ} \mathrm{C}$ dengan nilai maksimum $31,27{ }^{\circ} \mathrm{C}$ dan nilai minimum $29,72{ }^{\circ} \mathrm{C}$. Sedangkan rumahrumah tinggal yang ada tanaman peneduh pada tanggal 01-16 Desember 2018 menunjukkan ratarata $29,72{ }^{\circ} \mathrm{C}$ dengan nilai maksimum $30,15{ }^{\circ} \mathrm{C}$ dan nilai minimum $28,96{ }^{\circ} \mathrm{C}$. Dari hasil yang ditunjukkan temperatur pada rumah-rumah tinggal tersebut jauh diatas zona nyaman dan dapat disimpulkan bahwa kondisi kenyamanan termal untuk rumah tinggal di Perumahan Bukit Baruga Antang diatas zona nyaman yaitu $>27,1^{\circ} \mathrm{C}$, jika dibandingkan dengan standar kenyamanan termal SNI T-14-1993-03 yaitu hampir nyaman $25,8{ }^{\circ} \mathrm{C}$ - 27,1 ${ }^{\circ} \mathrm{C}$. Dari hasil uji t dapat disimpulkan kelompok rumah tinggal memiliki temperatur yang tidak sama. 


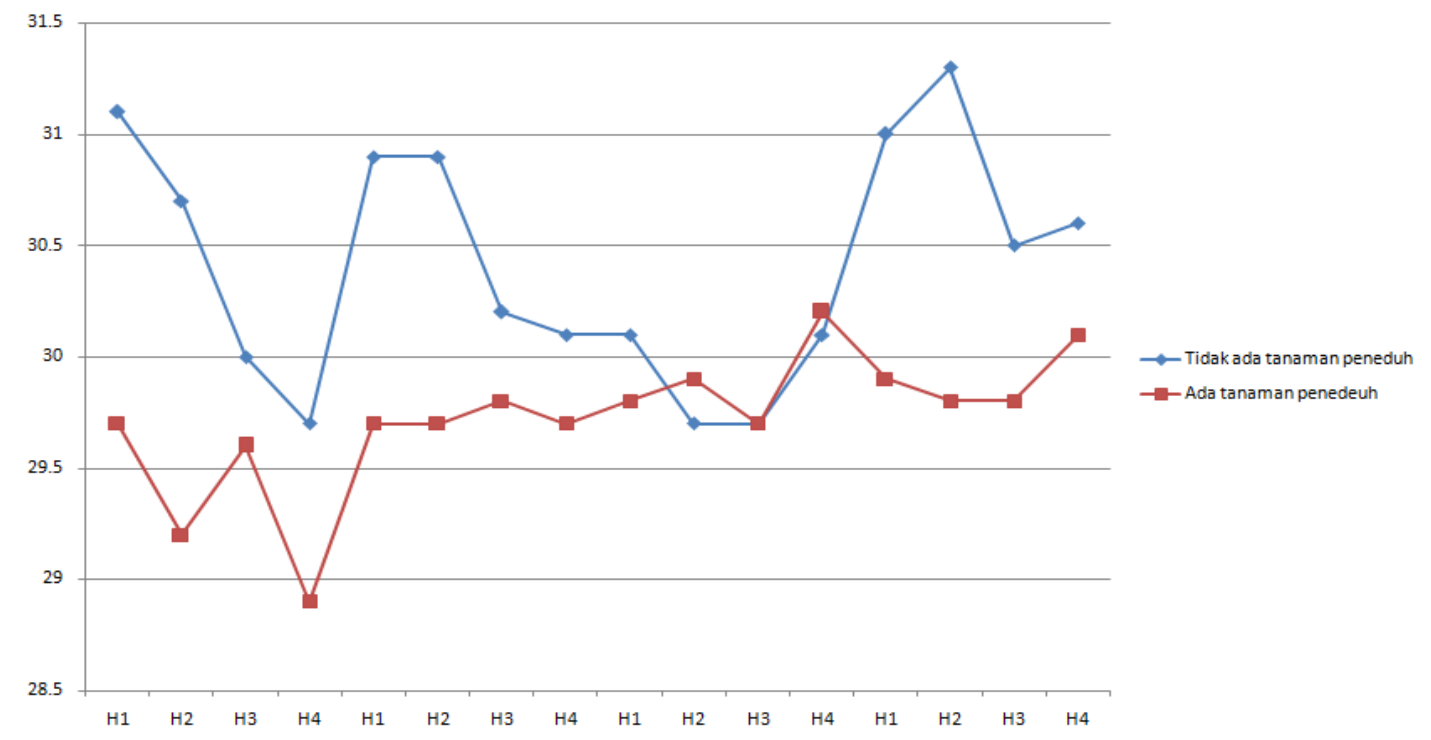

Gambar 3. Hasil pengukuran temperatur $\left({ }^{\circ} \mathrm{C}\right)$ rumah tinggal

Dalam makalah ini, perhitungan stabilitas kapal lebih ditekankan pada stabilitas statis pada kondisi intact (tidak ada kerusakan/gangguan pada kapal y Hasil penelitian kelembaban udara dapat dilihat pada Gambar 2, kelembaban udara dalam rumah-rumah tinggal yang tidak ada tanaman peneduh menunjukkan rata-rata $67 \%$ dengan nilai maksimum $73 \%$ dan nilai minimum $61 \%$. Sedangkan rumah-rumah tinggal yang ada tanaman peneduh menunjukkan rata-rata $65 \%$ dengan nilai maksimum $73 \%$ dan nilai minimum
61\%. Dari hasil tersebut menunjukkan bahwa kelembaban udara rumah-rumah tinggal di Perumahan Bukit Baruga Antang sudah cukup nyaman karena berada pada zona nyaman jika dibandingkan dengan standar SNI T-14-1993-03 menunjukkan kelembaban relatif zona sejuk nyaman 50\% - 80\%. Dari hasil uji t dapat disimpulkan tidak terdapat perbedaan kelembaban yang signifikan pada rumah tinggal yang tidak ada tanaman peneduh dan yang ada tanaman peneduhnya.

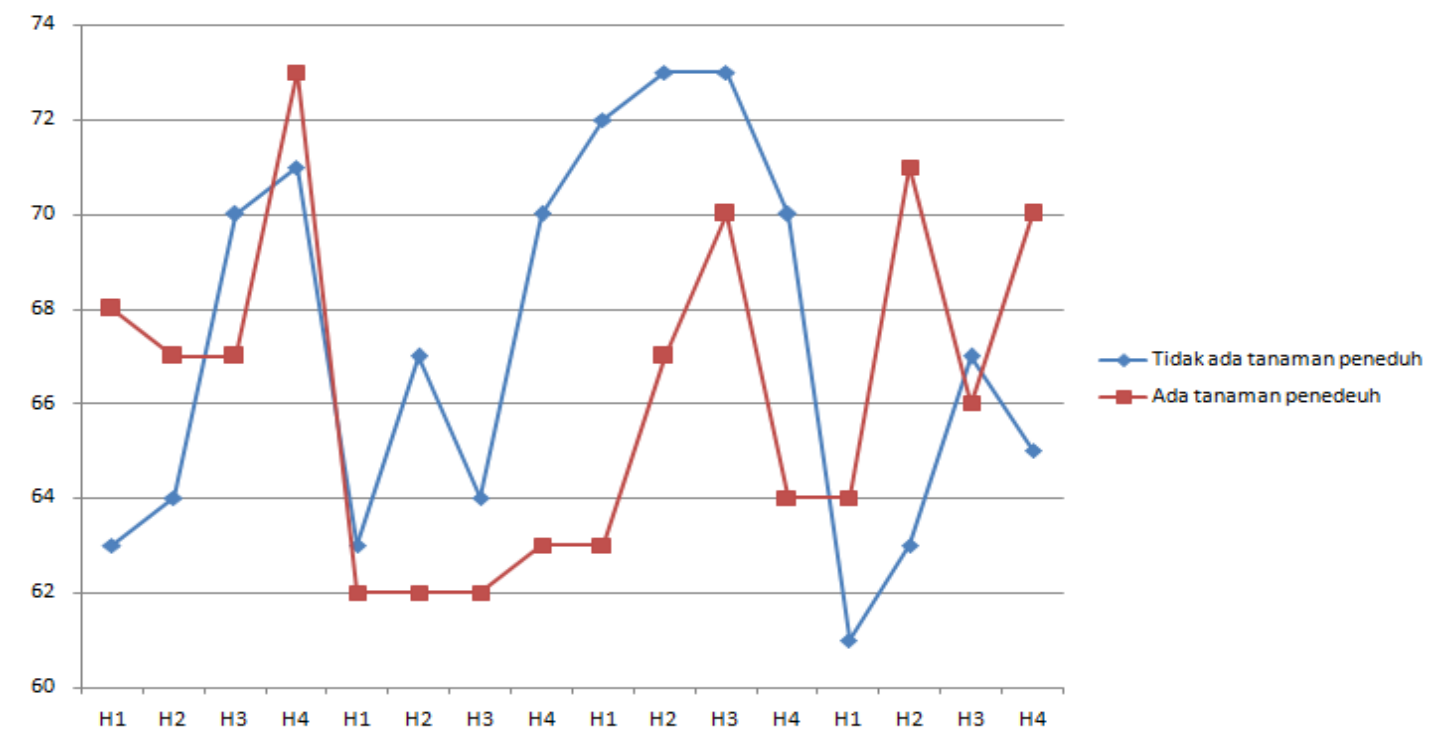

Gambar 4. Hasil pengukuran kelembaban (\%) rumah tinggal 
Hasil penelitian kecepatan aliran udara dapat dilihat pada Gambar 3, kecepatan aliran udara dalam rumah-rumah tinggal yang tidak ada tanaman peneduh menunjukkan rata-rata $0,15 \mathrm{~m} / \mathrm{s}$ dengan nilai maksimum $0,19 \mathrm{~m} / \mathrm{s}$ dan nilai minimum $0,11 \mathrm{~m} / \mathrm{s}$. Sedangkan rumah-rumah tinggal yang ada tanaman peneduh menunjukkan rata-rata $0,58 \mathrm{~m} / \mathrm{s}$ dengan nilai maksimum 0,65 $\mathrm{m} / \mathrm{s}$ dan nilai minimum $0,43 \mathrm{~m} / \mathrm{s}$. Dengan ini dapat disimpulkan bahwa kondisi kenyamanan termal untuk rumah tinggal yang tidak ada tanaman peneduh berada dibawah zona nyaman dan kondisi kenyamanan termal rumah tinggal yang ada tanaman peneduh sudah berada di zona nyaman jika dibandingkan dengan standar kecepatan aliran udara $(0,25-1,5 \mathrm{~m} / \mathrm{s}$ menurut Lippsmeir [5]. Dari hasil uji t dapat disimpulkan terdapat perbedaan kecepatan angin pada rumah tinggal yang tidak ada tanaman peneduh dan yang ada tanaman peneduhnya.

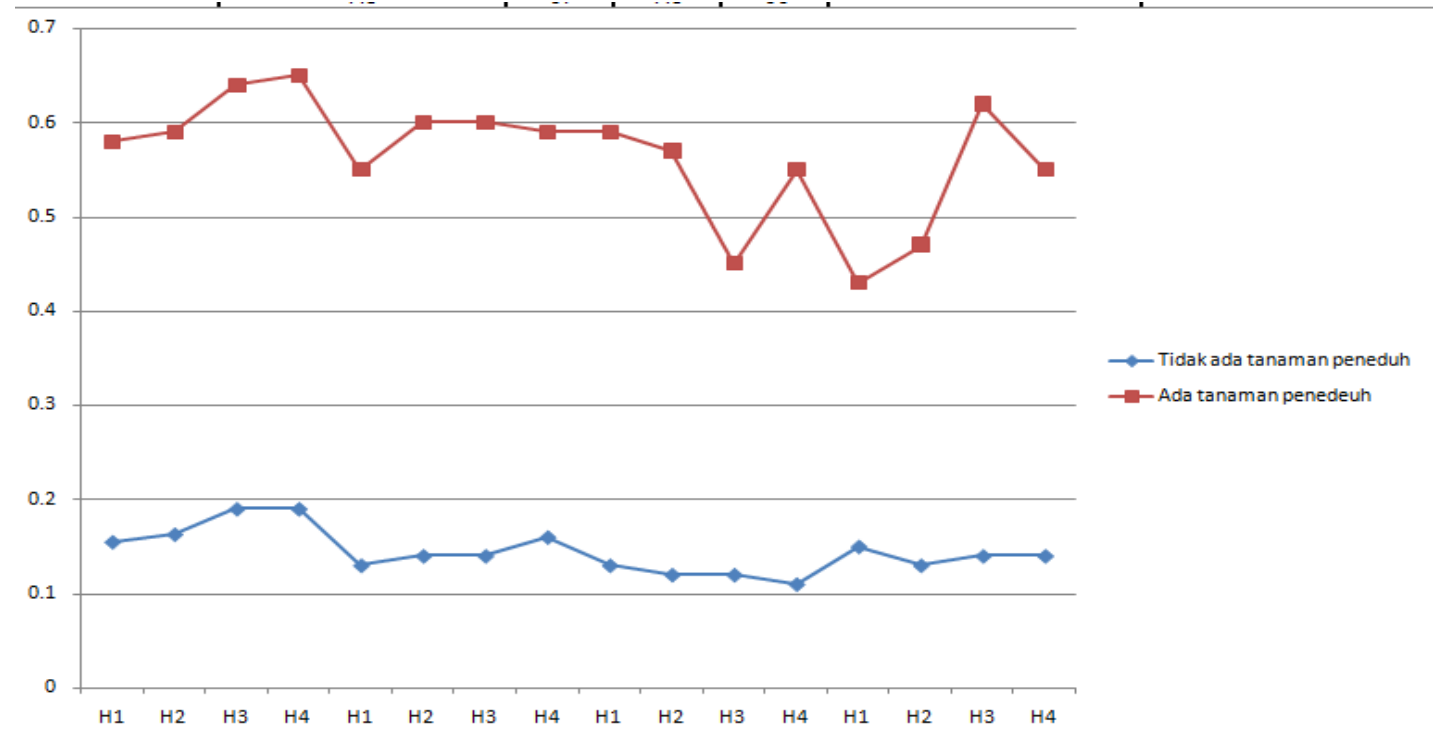

Gambar 5. Hasil pengukuran Kecepatan aliran udara rumah tinggal

\section{Hasil Survei Responden}

Hasil survei dari persepsi kenetralan termal dapat dilihat pada tabel 1, di ukur menggunakan nilai yang terbagi menjadi 7 kriteria yang disesuaikan dengan standar skala ASHRAE yaitu dingin (-3), sejuk (-2), agak sejuk (-1), netral (0), agak hangat (1), hangat (2), panas (3). Berdasarkan hasil yang didapat pada tabel 1 secara umum responden pada kelompok rumah tinggal yang tidak ada tanaman peneduh sebesar $75 \%$ dan sebagiannya lagi memilih netral nyaman dengan persentase sebesar $25 \%$. Sedangkan untuk kelompok rumah tinggal yang ada tanaman peneduhnya responden memilih $91,1 \%$ untuk kondisi netral nyaman, 7,1 \% untuk kondisi agak hangat dan 1,8\% memilih kondisi agak sejuk. Sehingga dapat disimpulkan responden pada rumah tinggal yang ada tanaman peneduh sudah cukup merasa nyaman pada kondisi kenetralan termal mereka berbeda untuk responden pada rumah-rumah tinggal yang tidak ada tanaman peneduh lebih memilih kondisi yang agak hangat.

Tabel 1. Data kenetralan termal

\begin{tabular}{cccc}
\hline Kriteria dan nilai & $\begin{array}{c}\text { Tidak ada } \\
\text { tanaman } \\
\text { peneduh } \\
(\boldsymbol{\%})\end{array}$ & $\begin{array}{c}\text { Ada } \\
\text { tanaman } \\
\text { peneduh } \\
(\%)\end{array}$ \\
\hline Dingin & -3 & 0 & 0 \\
Sejuk & -2 & 0 & 0 \\
Agak sejuk & -1 & 0 & $1,8 \%$ \\
Netral nyaman & 0 & $25 \%$ & $91,1, \%$ \\
Agak hangat & 1 & $75 \%$ & $7,1 \%$ \\
Hangat & 2 & 0 & 0 \\
Panas & 3 & 0 & 0 \\
\hline
\end{tabular}

Hasil survei preferensi termal dapat dilihat pada Tabel 2, rumah-rumah tinggal yang tidak ada tanaman peneduh terlihat $95,8 \%$ memilih lebih 
sejuk dan 4,2\% memilih tidak ada perubahan, sedangkan rumah tinggal yang ada tanaman peneduhnya $91,1 \%$ memilih lebih sejuk dan $8,9 \%$ memilih tidak ada perubahan.

Tabel 2. Data preferensi termal

\begin{tabular}{cccc}
\hline Kriteria dan nilai & $\begin{array}{c}\text { Tidak ada } \\
\text { tanaman } \\
\text { peneduh } \\
(\boldsymbol{\%})\end{array}$ & $\begin{array}{c}\text { Ada } \\
\text { tanaman } \\
\text { peneduh } \\
(\mathbf{\%})\end{array}$ \\
\hline $\begin{array}{c}\text { Lebih sejuk } \\
\text { Tidak ada } \\
\text { perubahan }\end{array}$ & -1 & $95,8 \%$ & $91,1 \%$ \\
Lebih hangat & 1 & $4,2 \%$ & $8,9 \%$ \\
\hline
\end{tabular}

Sedangkan hasil survei untuk keterterimaan termal dapat dilihat pada tabel 3, responden yang memilih sudah sesuai dengan kondisi tubuhnya sebanyak 31,9\% dan yang memilih tidak sesuai sebanyak $68,1 \%$ untuk rumah-rumah tinggal yang tidak ada tanaman peneduh, sedangkan untuk rumah-rumah tinggal yang ada tanaman peneduh yaitu $69,6 \%$ memilih ya sudah sesuai dan $30,4 \%$ memilih tidak sesuai.

Tabel 3. Data keterterimaan termal

\begin{tabular}{cccc}
\hline Kriteria dan nilai & $\begin{array}{c}\text { Tidak ada } \\
\text { tanaman } \\
\text { peneduh } \\
(\boldsymbol{\%})\end{array}$ & $\begin{array}{c}\text { Ada } \\
\text { tanaman } \\
\text { peneduh } \\
(\boldsymbol{\%})\end{array}$ \\
\hline $\begin{array}{c}\text { Ya (sudah } \\
\text { sesuai) }\end{array}$ & 0 & $31,9 \%$ & $69,6 \%$ \\
Tidak sesuai & 1 & $68,1 \%$ & $30,4 \%$ \\
\hline
\end{tabular}

Hasil survei kondisi kecepatan aliran udara dapat di lihat pada tabel 4, Pada penilaian kondisi angin terdapat 5 nilai yaitu lebih sangat sesuai (2), cukup sesuai (-1), sudah sesuai (0), tidak sesuai (1), sangat tidak sesuai (2). Semakin ke arah positif nilainya maka dapat diartikan penghuni cenderung merasa tidak sesuai, sedangkan apabila hasilnya negatif berarti penghuni cenderung merasakan kondisi aliran angin yang lebih sesuai. Pada tabel 4 menyatakan bahwa rumah-rumah tinggal yang tidak ada tanaman peneduh sebesar 8,3\% memilih cukup sesuai, 59,7\% memilih sudah sesuai dan 31,9\% memilih tidak sesuai. Sedangkan untuk rumahrumah tinggal yang ada tanaman peneduh $100 \%$ memilih sudah sesuai. Namun para penghuni rumah tinggal di perumahan bukit baruga ini tetap masih mengharapkan lebih banyak aliran udara lagi.

Tabel 4. Data kecepatan aliran udara

\begin{tabular}{lccc}
\hline Kriteria dan nilai & $\begin{array}{c}\text { Tidak ada } \\
\text { tanaman } \\
\text { peneduh } \\
\mathbf{( \% )}\end{array}$ & $\begin{array}{c}\text { Ada } \\
\text { tanaman } \\
\text { peneduh } \\
\mathbf{( \% )}\end{array}$ \\
\hline Sangat sesuai & -2 & 0 & 0 \\
Cukup sesuai & -1 & $8,3 \%$ & 0 \\
Sudah sesuai & 0 & $59,7 \%$ & $100 \%$ \\
Tidak sesuai & 1 & $31,9 \%$ & 0 \\
Sangat tidak & 2 & 0 & 0 \\
sesuai & 2 & & \\
\hline
\end{tabular}

Hasil survei kondisi kelembaban rumah tinggal dapat dilihat pada tabel $\mathrm{V}$, Pada penilaian kondisi kelembaban terdapat 5 nilai yaitu sangat lembab (-2), sedikit lembab (-1), sudah pas (0), agak kering (1), sangat kering (2). Semakin ke arah positif nilainya maka dapat diartikan penghuni cenderung merasakan terlalu kering, sedangkan apabila hasilnya negatif berarti penghuni cenderung merasakan kondisi sangat lembab. Pada tabel 5 menunjukkan untuk rumah tinggal yang tidak ada tanaman peneduh responden memili kondisi kelembaban yang sudah pas sebayank 97,2\% dan 2,8\% untuk kondisi yang agak kering, sedangkan pada rumah tinggal yang ada tanaman peneduh $100 \%$ responden memilih kondisi kelembaban sudah pas. Dengan ini dapat disimpulkan bahwa kondisi kelembaban pada rumah-rumah tinggal di Perumahan Bukit Baruga Antang sudah cukup nyaman.

Tabel 5. Data kondisi kelembaban

\begin{tabular}{cccc}
\hline Kriteria dan nilai & $\begin{array}{c}\text { Tidak ada } \\
\text { tanaman } \\
\text { peneduh } \\
(\boldsymbol{\%})\end{array}$ & $\begin{array}{c}\text { Ada } \\
\text { tanaman } \\
\text { peneduh } \\
(\boldsymbol{\%})\end{array}$ \\
\hline Sangat lembab & -2 & 0 & 0 \\
Sedikit lembab & -1 & 0 & 0 \\
Sudah pas & 0 & $97,2 \%$ & $100 \%$ \\
Agak kering & 1 & 2,8 & 0 \\
Sangat kering & 2 & 0 & 0 \\
\hline
\end{tabular}

Nilai tingkat aktivitas penghuni rata-rata 1 , karena para penghuni lebih sering menghabiskan 
waktu mereka di rumah dengan bersantai seperti berbaring, menonton, duduk, membaca dan tidur. Kegiatan-kegiatan tersebut nilai tingkat aktivitasnya sama dengan 1. Adaptasi yang dilakukan para penghuni untuk menyesuaikan dengan kondisi lingkungan yaitu mereka lebih sering memilih jenis pakaian yang cukup nyaman, tidak terlalu tebal dan mengurangi penggunaan pakaian yang berlapis. Penyesuaian di dalam rumah juga dilakukan dengan mengurangi aktivitas yang memicu banyak keringat.

\section{Kesimpulan dan Saran}

Dari hasil penelitian dapat kita simpulkan untuk dua kelompok rumah tinggal perbedaan yang dapat dilihat pada temperatur dan kecepatan angin. Untuk hasil penelitian kecepatan angin pada rumah tinggal yang ada tanaman peneduhnya berada pada zona nyaman yaitu sebesar $0,65 \mathrm{~m} / \mathrm{s}$, hal ini dikarenakan salah satu manfaat dari tanaman peneduh yaitu dapat memaksimalkan angin dan mengarahkan angin kedalam bangunan. Sedangkan untuk temperatur menunjukkan selisih yang masih sangat kecil sekitar $0,67{ }^{\circ} \mathrm{C}$. Hasil dari penelitian kelembaban untuk kedua kelompok rumah tinggal sudah mencapai standar yaitu berkisar pada 60-80\%. Dengan demikian pengaruh pembayangan dari tanaman peneduh mempengaruhi kecepatan angin pada rumah tinggal yang ada tanaman peneduhnya dan kondisi kelembaban masih berada pada zona yang nyaman.

Meskipun dari hasil penelitian menunjukkan hasil temperatur yang tinggi, namun secara keseluruhan responden masih merasakan kondisi yang nyaman dan mereka masih mengharapkan kondisi kenyamanan termal yang lebih baik lagi, kemungkinan responden masih dapat menerima kondisi saat ini karena sudah terbiasa terhadap kondisi yang mereka rasakan. Dibutuhkan penelitian lebih lanjut agar hasil pengaruh tanaman peneduh terhadap kenyamanan termal lebih akurat lagi.

\section{Referensi}

[1] Olgyay, V. 1963. Design with Climate: Bioclimatic Approach to Architectural Regionalism, Princenton University Press, New Jersey, USA.

[2] Lexi, Alex, 2008. Pengaruh Pembayangan Massa Bangunan terhadap Radiasi Panas Matahari di Ruang Terbuka Kawasan Tropis yang terletak pada Garis lintang $7^{\circ} \mathrm{LS}$, Yogyakarta.

[3] Wong, N.H, A.Y.K. Tan, Tan P.Y, Chiang K, and Wong N.C. 2010. Accoustics Evaluation of Vertical Greenery System for Building Walls. Building and Environment.

[4] Santoso, Eddy Imam, "Kenyamanan Termal Indoor Pada Bangunan Di Daerah Beriklim Tropis Lembab", Dalam Jurnal Indonesia Green Technologi Vol.No.1,2012.

[5] Lippsmeier, George, 1994. Bangunan Tropis. (S. Nasution Penerjemah). Jakarta, Erlangga. 